\title{
The Study of Economic, Social and Cultural Rights Indicators and Their Application in International Law
}

\author{
Peng Xu \\ Department of Criminal Investigation \\ Zhejiang Police College \\ Hangzhou, China
}

\begin{abstract}
Economic, social and cultural rights indicators have been gradually incorporated into the human rights framework. In practice, United Nations agencies, human rights treaty bodies and countries often use indicators to promote and monitor the implementation of economic, social and cultural rights. Because of the inherent shortcomings, human rights indicators do not accurately reflect the realization of economic, social and cultural rights. It would promote the role of human rights indicators in protection of economic, social and cultural rights, by combining statistical averages in human rights with information for specific groups, striking a balance between universal indicators and country-specific indicators, strengthening international cooperation efforts to collect comprehensive and reliable human rights data.
\end{abstract}

Keywords-economic; social and cultural rights; human rights indicators; human rights treaties

\section{INTRODUCTION}

Human rights indicator is an important tool for measuring the effectiveness of human rights policies and mechanisms. Human rights indicators can be used to express the abstract human rights values through the operational rules and objectively assess the extent to which human rights are "respected, protected and fulfilled". In 1992, the Committee on Economic, Social and Cultural Rights (CESCR) addressed in its report on the seventh session that the most pressing challenge for member states of the Convention was to demonstrate that their commitment to economic, social and cultural rights was a genuine and longterm promise. The best way to do so is to establish various standards by each state party so that full respect for the minimum core content of the basic rights can be verified by relevant governments.

\section{INDICATORS OF ECONOMIC, SOCIAL AND CULTURAL RIGHTS IN THE FRAMEWORK OF INTERNATIONAL HUMAN RIGHTS NORMS}

\section{A. The Relevant Provisions of Human Rights Treaties}

The economic, social and cultural rights indicators are clearly incorporated into the relevant provisions of human rights treaties. Article 12 of the International Covenant on Economic, Social and Cultural Rights requires states parties to take the necessary steps to "reduce the rate of stillbirth and infant mortality" for the full realization of the right to the highest attainable standard of health. Article 10 (f) of the Convention on the Elimination of All Forms of Discrimination against Women also provides that states parties are obliged to take measures to "reduce the rate of female drop-out" to ensure that women enjoy equal rights with men in education. Article 24 of the International Convention on the Rights of the Child emphasizes that states parties shall "take appropriate measures to reduce infant and child mortality rates"; Article 28 provides that states parties shall "take measures to increase student attendance and to reduce dropout rates".

\section{B. General Comments of Human Rights Bodies}

CESCR has issued a number of general comments on the use of indicators to monitor the implementation of economic, social and cultural rights. In general comment No.14, the committee provided right to health indicators and benchmarks. The general comment No.15 clarifies once again the indicators and benchmarks for the right to water. In its general comment No.27, the Committee on the Elimination of Racial Discrimination (CERD) asked the state parties "to include in their periodic reports, in an appropriate form, data about the Roma communities within their jurisdiction, including information on the participation of Roma in political life and its economy, social and cultural statistics." The Committee on the Elimination of Discrimination against Women (CEDAW), in its general comment No. 24, requested the state party to include in its report "the reduction in maternal mortality and morbidity in vulnerable groups, regions and communities."

\section{Other International Human Rights Instruments}

In 2004, Report of the Special Rapporteur "on the right of everyone to the enjoyment of the highest attainable standard of physical and mental health" provided a list of descriptive indicators to monitor the child survival rate as one of rights to health for children. The Human Development Report 2000, issued by the United Nations Development Program (UNDP), presents a general framework for the use of indicators to monitor the human rights situation. The World Health Organization (WHO) discussed the framework of the rights to health indicators in its 2004 report. The United Nations Human Settlements Program (UN-Habitat) (UNHRP) has developed a set of 
housing rights indicators. The United Nations Food and Agriculture Organization of the United Nations (FAO) has proposed indicators for the implementation of the right to food at the domestic level. In 2012, the Office of the High Commissioner for Human Rights (OHCHR) published the Human Rights Indicators: A Guide to Determination and Implementation, and developed a list of illustrative indicators of the right to food, the right to health, the right to education, the right to adequate housing, the right to social security and the work. In general, the indicator framework for measuring the achievement and progress of economic, social and cultural rights has been gradually established, and this framework is increasingly becoming a tool to monitor and implement the economy, social and cultural rights by international organizations, human rights institutions, governments, national human rights institutions and nongovernmental organizations.

\section{LIMITATIONS OF ECONOMIC, SOCIAL AND CULTURAL RIGHTS INDICATORS}

Indicators of economic, social and cultural rights have developed more rapidly than civil and political rights indicators. However, there are still some problems with application of economic, social and cultural rights indicators.

\section{A. The Average Value of Human Rights Indicators and Individual Rights}

Human rights assessments are usually based on average statistics on the human rights situation of certain country, rather than human rights data for specific groups such as the most vulnerable or marginalized groups in society. In essence, human rights indicators mainly depict the general conditions for the ultimate enjoyment of the rights of the individual, carrying out human rights analysis at the domestic level, which hardly help identify the rights of a considerable number of sub-populations within countries. Although human rights treaty bodies usually review human rights information about large groups of people, these rights are ultimately enjoyed by individuals. Average statistics in human rights assessments can't reflect the enjoyment of human rights by specific groups such as the most vulnerable or marginalized groups in society.

The United Nations Special Rapporteur, Danilo Turk, stated in "Economic, Social and Cultural Rights: First Progress Report" that since economic, social and cultural rights are individual rights, the general scope of many indicators may hinder its direct application and can't get a general overview of a particular situation. It should be recognized that both statistics are useful in conducting human rights impacts assessments. Average statistics can capture the general situation of human rights in a country, and human rights information for specific groups can better identify and help victims of human rights abuses. Thus, acquiring human rights information of a particular individual while acquiring the average number of human rights statistics of domestic population appears to better serve the purpose of human rights assessment, which can assess the extent to which each individual enjoys human rights in a society.

\section{B. The Universality and Specific Context of Implementation of Human Rights Indicators}

In theory, since human rights are based on the universality of the provisions of the Convention, standardized measurement for implementaion can be made. Human rights treaty bodies that review national compliance with human rights conventions should assess the effectiveness of the implementation of member states in accordance with these universal standards. A considerable part of the rights contained in the International Covenant on Economic, Social and Cultural Rights falls within the right to progressive realization of the largest available resources of a state. When measuring the implementation of these rights, the different available resources and periods between countries should be taken into account. The expression of "progressive implementation" and "maximum available resources" in the International Covenant on Economic, Social and Cultural Rights actually limits the scope of universally applicable human rights indicators. At the same time, in order to avoid the abuse of country-specific indicators by the state party, the Convention provides that "a minimum core obligation to ensure the satisfaction of, at the very least, minimum essential levels of each of the rights is incumbent upon every state party." If a state argues that the minimum core obligation can't be met because of resource constraints, the state must demonstrate that it has tried to use all available resources to ensure the core rights of all.

The contextualization of indicators related to economic, social and cultural rights may lead to that the same data obtained in different countries will result in different conclusions of compliance with human rights obligations. The universal indicators can't fully measure the compliance of the country; neither can they provide an in-depth analysis of the causes behind human rights violations or solutions to human rights problems in specific countries. If human rights indicators are more realistic, they could be more meaningful and more likely to be used. As Katarina Tomasevski points out, applying the same standards of conduct to all states, as if all states had the same infrastructure, institutions and resources, was not only unfair but also ignored one of the main objectives of international cooperation in the field of human rights. Thus, when assessing compliance with human rights treaties, country-specific indicators should be applied prior to the universal ones, which may choose the indicators that are most relevant to each country and the relevant treaty provisions.

\section{The Accuracy of Human Rights Indicators and Statistics of the Data}

At the ideal level, human rights assessments should be fully aware of the respect, protection and fulfillment of obligations by the entire state. But in reality, the assessment agency can only get those reported violations of the situation. Many of the actual violations have not been reported at the national or international level, thus limiting the availability of human rights-related information. Using such statistical data in the framework of the human rights assessment may lead to deviations. In many human rights assessments, especially when analyzing specific situations, it is difficult to 
obtain human rights enjoyment or abuse by the relevant groups due to the lack of statistical data required for specific criteria, and it is meaningless to assess the human rights situation relying on indicators. For example, when we develop indicators of "appropriate living standards", the data on homeless numbers has a great importance in testimony, but the availability of this indicator is limited by a serious lack of relevant information. In fact, some data of the most critical indicators of economic, social and cultural rights, such as homelessness, income distribution, etc., have been collected only by few countries and international agencies. As a result, these indicators lose their indicative value.

In addition, the effectiveness, reliability, objectivity of data is also the core elements of human rights indicators. If there is no reliable data to support, human rights indicator largely could lose the empirical significance. In practice, human rights assessments rely primarily on national selfreported data (eg, periodic reports). The state chooses the method of collecting data and decides which human rights indicators to use to allow treaty bodies to assess the human rights achievements of the state. The reliability of such data is sometimes questionable because the data can easily be altered or tampered with, resulting in misinterpretation of a particular situation or social reality. Thus, indicators do not always be able to effectively reflect human rights conditions and are likely to be a simple way for countries to avoid accusing them of their underlying causes of poverty and related problems.

\section{IMPLICATION FOR CHINA}

As mentioned above, human rights indicators have inherent weaknesses and shortcomings. So, a failure to reach a benchmark does not necessarily mean that the State is in breach of its international right to health obligations. Nonetheless, the role of human rights indicators in measuring the effectiveness of human rights protection can't be ignored. In the realization of economic, social and cultural rights, human rights indicators continue to guide and support countries to meet economic, social and cultural commitments. In this sense, economic, social and cultural rights indicators can provide potential technical assistance to states party.

As a guarantor of international treaties on economic, social and cultural rights, Chinese government has increasingly used human rights indicators to assess the extent to which economic, social and cultural rights are achieved. At the international level, human rights indicators guide China to provide authoritative and reliable reference materials in the compliance reports submitted to the human rights treaty bodies to help China better fulfill its treaty obligations. At the domestic level, the statistical data of the indicators can accurately reflect the problems in the realization of China's economic, social and cultural rights and its gap with other countries, which can better improve the human rights situation.

On the other hand, there are still many problems with the application of human rights indicators in China. Firstly, there is a lack of comprehensive data on the relevant rights, and the type of indicators is set incompletely. In its concluding observations on China's second periodic report, CESCR requested China to include in its next periodic report comparable annual data and data for urban areas, as well as data on poverty reduction and poverty eradication. The committee also pointed out that China currently does not have statistics on unemployment by ethnicity, which limits the assessment of the enjoyment of the right to work of ethnic minorities. Secondly, the realization of the rights of specific groups can't be identified. In the second periodic report, China provided the urban registered unemployment rate from 2003 to 2009, but did not classify social groups on the basis of sex, age and occupation. To this end, the CESCR Pre-sessional Working Group stated in the "List of issues in relation to the second periodic report of China" that, the Chinese government need to indicate whether the official statistics of the urban unemployment rate includes unemployed migrant workers, laid-off workers, unemployed university graduates, as well as men over the age of 60 and women over the age of 50 and other categories of population. Thirdly, qualitative and quantitative indicators are not complementary and mutually supportive. In the second periodic report, Chinese government declared that it had formulated relevant laws and regulations to solve the employment problems of migrant workers and college graduates. However, the report does not address what measures have been taken to address the high unemployment rate of ethnic minorities in accordance with the 2007 Employment Promotion Act, nor does it explain its impact.

\section{CONCLUSION}

In order to make human rights indicators an effective tool for monitoring the implementation of economic, social and cultural rights, Chinese Government, when applying the economic, social and cultural rights indicators, should first establish and improve the data collection system related to economic, social and cultural rights on the basis of the existing economic and social development statistics database, and compile the latest annual statistical and statistical analysis of the rights recognized in the International Covenant on Economic, Social and Cultural Rights. Secondly, universal indicators and indicators for specific individuals need to be considered in combination and a modest balance between the universal indicators and indicators of specific groups is sought to keep obtaining comprehensive and reliable human rights statistics. Finally, within the framework of human rights protection, not only the qualitative indicators such as human rights protection legislation and human rights protection policies should be incorporated, but also quantitative measures such as measures taken to implement the relevant legislation and policies, and the extent to which individuals enjoy the rights. From the current practice of China, the creation of detailed, systematic and authoritative economic, social and cultural indicators still requires a long period of exploration. The effectiveness of human rights indicators ultimately requires long-term practice tests to draw an objective and rational conclusion. 


\section{REFERENCES}

[1] Danilo Turk, The Realization of Economic, Social and Cultural Rights, July 1990 (Progress Report), UN Doc. E/CN.4/Sub.2/1990/19. Available at: https://documents-ddsny.un.org/doc/UNDOC/GEN/G90/123/80/PDF/G9012380.pdf?Open Element.

[2] UNDP Human Development Report 2000, "Human rights and human development". Available at: http://hdr.undp.org/en/content/humandevelopment-report-2000

[3] Katarina Tomasevski, Indicators, in Economic, Social and Cultural Rights:A textbook, in Asbjørn Eide, Catarina Krause and Allan Rosas eds., Brill Academic Publishers, 2001. Available at: http://web.abo.fi/instut/imr/publications/books/9041116133.htm.

[4] Paul Hunt, Special Rapporteur on the right of everyone to the enjoyment of the highest attainable standard of physical and mental health, reports to the General Assembly, 2003 (A/58/427) . Available at: http://hria.equalit.ie/pdf/en/5/58-427\%20EN.pdf.

[5] UN-HABITAT, Monitoring Housing Rights, Developing A Set of Indicators to Monitor The Full and Progressive, Realisation of The Human Right to Adequate Housing, 2003. Available at: http://mirror.unhabitat.org/documents/Monitoring-HousingRights.pdf.

[6] WHO, Consultation on Indicators for the Right to Health,1-2 April 2004, Meeting Report. Available at: http://www.who.int/hhr/activities/Report\%20indicatorsmtg04\%20FIN AL.pdf.

[7] Paul Hunt, Economic, Social and Cultural Rights, Report of the Special Rapporteur on the Right of Everyone to the Enjoyment of the Highest Attainable Standard of Physical and Mental Health, E/CN.4/2006/48. Available at:https://documents-ddsny.un.org/doc/UNDOC/GEN/G06/114/69/PDF/G0611469.pdf?Open Element.

[8] Food and Agriculture Organization of The United Nations, The Right to Food in Practice, Implementation at The National Level, 2006. Available at: http://www.fao.org/docrep/016/ah189e/ah189e.pdf.

[9] Indicators for Human Rights Based Approaches to Development in UNDP Programming: A Users' Guide,UN Development Programme,March 2006, p.11. Available at: http://gaportal.org/sites/default/files/HRBA\%20indicators\%20guide.p df.

[10] Gauthier de Beco. Human Rights Indicators for Assessing State Compliance with International Human Rights, Nordic Journal of International Law. Vol.77, 2008.

[11] Sital Kalentry, Jocelyn Getgen, Steven A. Koh, Measuring State Compliance with the Right to Education Using Indicators: a Case Study of Colombia's Obligations Under the ICESCR, Cornell Law Faculty Working Papers, 2009. Available at: http://scholarship.law.cornell.edu/clsops_papers/52/.

[12] Sital Kalantry, Jocelyn E. Getgen, Steven Arrigg Koh, Enhancing Enforcement of Economic, Social and Cultural Rights Using Indicators: A Focus on the Right to Education in the ICESCR, Human Rights Quarterly 32, 2010.

[13] General Comment No. 3 of Committee on Economic, Social and Cultural Rights, the nature of the obligation of States parties (article 2, paragraph 1, of the Convention), E / 1991/23, 1990. Available at: http://www.refworld.org/docid/4538838e10.html.

[14] List of issues relating to the second periodic report of the People's Republic of China, including China Hong and Macao, China, by the pre-sessional working group of the Committee on Economic, Social and Cultural Rights, E/C.12/WG/CHN/Q/2, 13 June 2013. Available at: http://tbinternet.ohchr.org/_layouts/treatybodyexternal/Download.asp $\mathrm{x}$ ?symbolno=E\%2FC.12\%2FWG\%2FCHN\%2FQ\%2F2\&Lang=en.

[15] Committee on Economic, Social and Cultural Rights, concluding observations on the second periodic report of China (including Hong Kong, China and Macao, China) E/C.12/CHN/CO/2, 2014. Available at: ttp://www.cmab.gov.hk/doc/en/documents/policy_responsibilities/IC ESCR_Concluding_Observation.pdf. 